\title{
Stealth Radicalism: Teaching Refugee Rights as Human Rights
}

\author{
By Steven Jones
}

$\mathrm{I}$ n this essay, I describe a Human Rights course in which I focused on refugee rights through a servicelearning project with a refugee resettlement agency, which I will refer to as Genesis. I will summarize my own approach to "radical teaching," my objectives for the course, the course itself, and the impact of the course on the students. Ideally, I would describe the impact on the refugees with whom the students interacted, but I was not able to collect narratives in that regard.

I taught this course in the Spring semesters of 2007 and 2008. The course was offered as a special topics course in political science at a large, urban, public research-intensive university in a relatively conservative Midwestern state. For this reason, I have titled my essay "stealth radicalism" because I have found in teaching to relatively conservative student populations that a direct radical approach is often self-defeating. Conservativelyminded students tend to resist teacher-directed challenges to their worldviews. On the other hand, when experience and course content challenge their worldviews, such students tend to be less threatened and can be more open to taking a critical stance to long-held beliefs. That was the strategy I applied in this case.

Although I probably fit the description "radical" in my personal beliefs, I am a pragmatist when it comes to teaching. My teaching experience in college courses, which began in 1983, has convinced me that students in my courses are politically oriented in one of three ways. They are ideologically conservative, ideologically liberal (though rarely radical), or they are politically and ideologically indifferent. Consequently, in teaching political science courses, I have found that stealth approaches that nudge conservative students to re-examine their positions are more productive in helping them develop self-critical approaches to their assumptions than direct confrontation from me. This approach is similarly true for the politically indifferent students. I also ask the liberally-minded students to likewise examine their beliefs and they are either radicalized or they find confirmation of their values and beliefs.

\section{Description and Context of the Course}

During the period in which I taught this course, the Bush administration was still heavily entrenched in the Iraq war and the detainment of "enemy combatants" was in full swing at Guantánamo. Given this context, I had several goals for the course. One was to examine human rights in the context of the war on terror and the degree to which the war had undermined U.S. and Western commitments to human rights, particularly political and civil rights. Another was to examine human rights through the perspective of refugee rights. The city in which I taught this course was a refugee resettlement location, and a local non-governmental organization was the only organization in the area that focused on refugee resettlement. Students worked directly with refugees through a service-learning project with this organization. Both of these goals were explicitly stated objectives for the course. The full set of course objectives is listed in Appendix 1, the course syllabus.

Another of my objectives for the course was not explicitly stated for the students: conscientization of the students through their experiences with refugees. By conscientization I mean Paolo Freire's concept by which the individual gains a "critical comprehension of man [sic] as a being who exists in and with the world" and "[is] able to achieve the complex operation of simultaneously transforming the world by their action and expressing the world's reality in their creative language" (Freire, 1998, 499). Thus, I wanted my students to understand their place "in and with the world" as not only rights-bearing individuals under current human rights norms and laws, but as duty-bearing individuals capable of consciously 
changing social reality with respect to human rights in general, and refugee rights in particular. I also hoped that their "creative language" would evolve over the period of the course such that they understood their own power to address the social injustices imposed on refugees by U.S. policy, and to help them empower refugees and their agents as well.

\section{I have found that stealth approaches that nudge conservative students to re-examine their positions are more productive in helping them develop self-critical approaches to their assumptions than direct confrontation from me.}

Another of my implicit goals for the course was to provide students with opportunities to critically evaluate their own values and beliefs, particularly with respect to $U$. S. policies related to the war on terror and refugee resettlement. This is another aspect of conscientization; one cannot understand one's relationship in and with the world without this kind of self-analysis. Otherwise, one is merely a recipient of the values, norms, and beliefs imposed by others (Freire, 1998). I wanted the students to critically evaluate the war in Iraq, the war on terror, and U.S. refugee policies in light of the human rights and humanitarian standards we would be studying.

These opportunities came primarily through students' service-learning experiences and their personal reflections on those experiences. In their reflections, I asked students to address the following questions:

- Is the United States doing enough with respect to refugee assistance, particularly with respect to refugee resettlement? Why or why not?

- In what ways does your work with Genesis [a pseudonym for the actual organization] help you better understand Martha Nussbaum's concept of capacities, or Galtung \& Wirak's concept of basic human needs?

- How does your work with Genesis affect your definition or thinking about duty-bearers with respect to human rights? Who are dutybearers?

- How does the specific work of Genesis compare with the general descriptions of NGOs provided by Forsythe in Chapter 7 and Claude in Reading \#31 in the Claude and Weston text? For example, is Genesis more like an advocacy organization or a relief organization, as defined by Forsythe? Which of the functions described by Claude does Genesis perform? How does your work with Genesis help you understand the role of NGOs in protecting human rights? ${ }^{1}$

\section{About Service-Learning and the Service Learning Project ${ }^{2}$}

For those who are unfamiliar with service-learning, it is a pedagogical technique through which students develop a deeper understanding of course concepts and skills through organized, community-identified service activities that provide mutual benefits for the server and the served and in which students reflect on their service experiences in terms of personal, academic, and social development. Service-learning as a pedagogy is not without its critics. For example, Butin (2006) argues that service-learning in practice can reinforce the power distance between server and served and is a pedagogy that frequently serves the interests of campus administrators to provide "transformational" experiences for students rather than pursuing social justice for marginalized communities. Morton (1995) notes that the prevalent model of servicelearning is a "charity" model in which students do for or to individuals and communities, maintaining a dependent relationship between server and served. He contrasts this with a "social justice" approach in which server and served are engaged in equitable, mutually beneficial partnerships, for which the ultimate aim is the empowerment and liberation of marginalized individuals and communities. ${ }^{3}$ Notwithstanding such critiques, I am a proponent of service-learning as a pedagogical approach to radical teaching so long as the following provisos are met:

- Service-learning activities are planned with the community partner and the community partner has a voice in the implementation and evaluation of the activities.

- Students are given as thorough an introduction as possible to the population being served and are asked to reflect on their assumptions, preconceptions, and potential biases and stereotypes relative to members of that population.

- Students are required to examine their stereotypes and biases prior to the service experience and are continuously required to reflect on their biases and stereotypes throughout the experience, particularly with respect to issues of power and power distance.

I tried to meet these provisos by holding an in-class, pre-service orientation with the director of the refugee settlement agency to provide an introduction to the agency and its clientele; by showing a documentary film about a refugee family, its life in a camp, and the difficulty of the transition from camp to residence in the United States; and by requiring students to examine their beliefs and stereotypes about refugees through their reflection essays.

The service-learning component of the course required students, either individually or in groups, to provide services to refugee families as directed by the agency. Such services included helping individuals and families register for social services, including registering children in local schools; helping families with navigating the 
bureaucracy of setting up utilities for their apartments; helping families transition to life in the United States by engaging in "typical" activities like going to movies or going out to eat; accompanying individuals to physician's appointments; and assisting with English as a Second Language classes for refugees. I required students to provide a minimum of fifteen hours of service to the agency, but several students provided much more. Indeed, several students continued volunteering for the agency long after the semester ended.

\section{Impact of the Service-Learning Experience on Students}

In the section that follows, I analyze the impact of the experience in relation to my stated goals through examining selections from students' reflections. A total of twenty-seven students completed the course over its two offerings. Of those, twenty-two were female and five were male. I have selected the reflections from four students, whom I will call Frank, Melissa, Karen, and Laura (not their real names), as representative examples of students' reflections. Frank is representative of the conservative student, Melissa the politically indifferent student, and Karen and Laura the liberal students. The impact of the service-learning experience on my students based on the goals I stated above was mixed. Some students did critically evaluate their own perspectives on human rights and U.S. human rights policy, and others ended the course with the same attitudes and beliefs that they had at the beginning.

\section{Impact of the Course on Students' Understanding of the Impact of the War on Terror on Human Rights}

As the reader can see from the reflection questions and Appendix 3, I did not ask students to directly relate their service-learning experience to the war on terror. Most of those connections were made through in-class discussions of the course readings, particularly the essays collected in Wilson (2005). One of the final exam questions asked the students:

Neil Hicks claims that the post 9/11 'war on terror' has done damage to the international human rights system, resulting in 'the erosion of state respect for human rights, fundamental freedoms, and the rule of law. The pretext of counterterrorism has sparked a race to the bottom in compliance by states with their human rights obligations.' (Hicks in Wilson, 2005. p. 221). Based on the authors we have read, what evidence exists to support Hicks's claim? What evidence is there that the state of the international human rights system may not be as badly damaged as Hicks claims?
This question allowed students to critically evaluate the impact of the war on terror on human rights from multiple perspectives.

Laura's response to this question reflects a conclusion reached by several of the students in the course:

Human rights should be the fundamental concern for nation-states. However this viewpoint is not always shared within or between nation states . . . Richard Falk [2005] and Richard Goldstone [2005] both agree that the war on terror has done damage to human rights standards. U.N. Secretary General Kofi Annan noted that, "When human rights are violated, all our rights are put in jeopardy and all of us are made less safe" (Hicks in Wilson, p. 210). I agree with this quote because to violate one human right, opens a playing field to other human rights violations.

She continues:

The "age of terror" has placed security at the center of the U.S. political agenda, devaluing important issues like poverty, globalization, AIDS, pandemics, global warming, and human rights issues (Dr. Jones lecture 04/17/07). The U.S. is known as a superpower in the world; if they choose to devalue human rights than they are setting a global agenda to do the same. This is a bad trend to begin because how can human rights as well as these other issues be successfully addressed, if they in fact are not being addressed at all? There have been some trade-offs for increased securities, but have these trade-offs made anyone more secure? There is no promotion of human rights, no collective consciousness, and the movement towards international realization of human rights is not robust by any means.

Laura's comments reflect the idealistic and liberal orientation of many of her classmates.

In addition to reflecting on course readings, students in the Spring 2007 course also had the opportunity to attend a lecture by Kevin Yee, the Army chaplain that had served at Guantánamo who was wrongly imprisoned as an "enemy combatant." During his lecture, Yee described the mistreatment of prisoners at Guantánamo as well as the direct injustices he personally experienced. Prior to attending Yee's lecture, students read David Rose's (2004) journalistic exposé of conditions at Guantánamo. In her analysis and reflection on Yee's lecture, Karen observed that not only did the policies associated with the U.S. war on terror lead to the violation of detainees' rights, they were ultimately counterproductive in combatting terrorism:

According to the Guantanamo book we are reading [Rose, 2004], there was no evidence that some of the detainees ever carried arms, and they were not captured at any battlefield. International treaties clearly show that they deserved humane 
treatment. (But even if they were terrorists, they shouldn't have been treated in that manner.) Personally, I was disgusted at the extent to which this "war against terror" was being carried out at the expense of human rights.

This presentation also brought what Freeman [2005] was talking about to reality for me. He lists several actions taken out by the U.S. government after 9/11 that may lead to some resentment in the "rest" of the world. These are 1.Doctrine of preventive self-defense.

2. The willingness to resort to war.

3. Reluctance to submit to international regulations, even on human rights and arms control

4.The substitution of 'coalition of the willing' for multilateral action

5. Disregard for inconvenient international laws

I think we see some evidence of a backlash as a result of all the military actions that are being taken in the name of fighting terrorism. Ignoring the very basic human rights that this country advocates it stands for and associates with its very inception, would not produce the desired result, ridding the world of terror.

As these excerpts indicate, as a result of their readings and discussions students were able to critically evaluate the impact of the U.S. "war on terror" on human rights. Implicit in their comments was a recognition of the gap between the U.S. stated values with respect to democracy and human rights, and the reality of U.S. actions at home and abroad in its execution of the war on terror. However, as I note below, not all students believed that the gap was unbreachable.

\section{Impact of the Course on Students' Sense of Solidarity with Refugees}

One of the potential positive impacts of servicelearning is that students have contact with the lived experiences of individuals and groups who would otherwise be abstractions, as in the case of "refugees." Through their interaction with our partner agency and the refugee families with whom they worked, the students gained insights into the refugee experience that they probably would not have developed through course readings or films. For example, Frank noted the potential cognitive dissonance that refugees face as they adjust to life in the United States:

the experience has as mentioned before, made me think about the perceptions of not only other countries but also of peoples throughout the world who may misunderstand our nation's goals or view on foreign policy due to seeming inconsistencies and some may even claim in the U.S. that there are a good many inconsistencies. I may find it believable that someone from Burma who comes to the U.S. and is graciously helped by Americans may find it odd later on that we are at war throughout the middle-east and have military policing all over the world. The strict order and military strength over the people in Burma may lead a refugee to question a lot of the relation or mentality that may or may not be similar to the government in Burma and the one here.

Melissa, who helped in the English as a Second Language classes for refugees, began to realize the limitations of U.S. refugee assistance programs given the challenges refugees face:

Although I see my group of clients improving with their English, it is evident that the process of adapting to American culture and the English language is something that will take a considerable amount of time. Unfortunately, Genesis only is able to assist the refugee families for six months after they arrive in the U.S., and then they are either on their own or transitioned to another organization to provide continued assistance. Due to limited resources and volunteers, organizations such as Genesis find it difficult to sustain efforts to help refugee families adapt to a new culture, government, and way of life. This dilemma poses questions about the current situation in the international community and how it treats or should be responsible for human rights and refugees.

Melissa's growing awareness of the gap in U.S. policy between professing support for human rights and unwillingness to provide material support for these rights creates a possible space for developing a more radical perspective on human rights in theory and practice.

\section{As a result of their readings and discussions students were able to critically evaluate the impact of the U.S. "war on terror" on human rights. Implicit in their comments was a recognition of the gap between the U.S. stated values with respect to democracy and human rights, and the reality of U.S. actions at home and abroad in its execution of the war on terror.}

\section{Impact of the Course on the Conscientization of Students}

In his final reflection, Frank noted, "I do not think my perceptions have changed so much [from the beginning of the course] . . . when it comes to U.S. policy on resettling refugees." However, he went on to note the problems with U.S. refugee policies: 
I found it interesting that religious persecution is a category in itself and it is apparent that our foreign policy keeps that at the top in every section where it is referenced on the [U.S. State Department] report. I overall always had the impression from class and from past studies that the U.S. focuses on helping refugees that are in very volatile areas that have been relocated due to oppression and tyranny which seems fitting and almost inherent in what many think of "America" and that is clearly evident by the thousands of refugees we have resettled from Somalia, Sudan, Burma, etc. The other thing that is $\quad$. . clearly evident is the political bias in the numbers and places where we are taking refugees which is also evident in the numbers such as China compared to Cuba. China seems like it is at least equally oppressive as Cuba if not more and China cannot fairly be compared in size of population to Cuba and yet there are more from Cuba than China? This is an example of where our foreign policy encompassing refugee resettlement becomes evident that there are some statements being made politically. Overall this is the impression I had of U.S. refugee policy; yes we help out those in crisis situations around the world, but we also keep in mind what may be more politically advantageous to our established foreign policy.

Implied in Frank's reflection is the realization that U.S. refugee policies, however humanitarian, are guided by values based on security and political interests and not necessarily in the interests of refugees. Acknowledging that a policy that he initially believed was beneficent was actually motivated by national self-interest is an awareness of the discrepancy between the world as we believe it is and the world as we learn that it is. To me, this is part of the process of conscientization, similar to what John Dewey (1910, 10-11) referred to as perplexity.

Melissa also experienced conscientization as a result of her direct experience with refugees and her growing familiarity with the international norms and laws related to the protection of refugees. For example, in one of her earlier reflections on who are duty-bearers with respect to refugee rights, she wrote, "Although states are usually seen as responsible for ensuring the protection of human rights, this does not mean they are obligated to step in when it comes to the protection and assistance of refugees." In my feedback, I asked her to re-examine that claim in light of her service experience and a review of the pertinent international norms and treaties regarding refugees. In her final reflection, she re-answered her question regarding states' obligations with respect to refugees:

According to "Recommendation $D$ " in the introductory note of the Convention and Protocol Relating to the Status of Refugees issued by the United Nations High Commissioner for Refugees, "The conference, considering that many persons still leave their country of origin for reasons of persecution and are entitled to special protection on account of their position, recommends that Governments continue to receive refugees in their territories and that they act in concert in a true spirit of international cooperation in order that these refugees may find asylum and the possibility of resettlement. "14 Therefore as members of the international community, states are seen as responsible for the fair treatment and protection of refugees. However, even though there are international norms and laws addressing human rights concerns such as the treatment of refugees, a major concern is that often these laws and/or norms are not effectively enforced.

However, conscientization does not simply mean gaining new understanding in light of new information, of which Melissa's experience is an example. It means recognizing the possibility and potential for remaking the world: not simply understanding the world as it is, but understanding the world as it can be and taking action to remake the world. Melissa's reflection on who are dutybearers with respect to refugee rights delves deeper into the role of non-governmental organizations and the responsibility of everyday citizens. She concludes by noting that once one understands the international norms and laws protecting refugees and the actual lived experiences of refugees, then one does have an obligation to provide support to refugees:

What I have learned and witnessed so far at Genesis has given me insight as to who should be responsible for refugees. We need to remember we are all people and we should consider how others are affected by political and economic turmoil, because we do not know if someday we may be in a similar situation. Before this course, $I$ was not aware of the Burmese population in town and I wish I would have known more about it before now because it seems there could have been much that I could have done to assist with their process in transitioning to American life.

This growing awareness of the need to put theory into practice, what leftist thinkers refers to as praxis, is perhaps another goal of the stealth radicalism of the course.

\section{Impact of the Course on Students' Self- Evaluation}

I submit that some of the student reflections that I have already referenced provide evidence of the selected students' ability to examine their own beliefs and values with respect to U.S. policies relative to the war on terror, human rights, and refugees. In some cases, as noted in the reflections from Frank and Melissa, students came to see that what they had initially believed was "good" about U.S. refugee policies was problematic. In other cases, students had a renewed sense of how to act on their beliefs

\section{RADICAL TEACHER}


and values relative to human rights. For example, Laura, in her final reflective essay noted:

I look to my future and can see how programs like Genesis help to give a start to refugee families. I think that this class has helped me to see what I am really passionate about and to not sit around while human rights need to advance into the future. I do not understand how a person or group of people can violate human rights but it needs to stop. One of the good things that I can walk away with is the refugees that $I$ have worked with are showing that life does go on. Maybe America is their destination and I am glad they escaped their prior life experiences, but I feel that they should not have had to experience those events. As knowledgeable people we all should be looking towards how we can make a difference and enhance human rights. To see how much you have and how little others have not only materially but as individuals rights, I know that there can be more that all can do for the benefit of others. It is one thing to say you will do something but we should take that next step and actually do, by doing we will see the positive changes in the fight for human rights.

Laura's experience shows how the service learning component of class on refugee issues as human rights can move students beyond a passive acceptance of the status quo.

Laura realized that she was "passionate about" human rights in a way in which she could align her values with action. This is the apex of conscientization through which one realizes not only one's place in the world, but one's ability to act on and shape the world as opposed to being shaped by the world. I am proud to say that I have maintained contact with Laura since this class. Following graduation from the university, she spent a year working in one of the Native American nations as a school teacher. She is currently pursuing a graduate degree in rural development, where she can put her passion for human rights into concrete strategies to work with and empower the rural poor.

\section{Conclusions}

As I reflect on this course and its effect on my students, several conclusions come to mind. On the one hand, I believe that, overall, my goals for the course and for the students were satisfied. Students did critically evaluate U.S. policies with respect to the war on terror and its negative impact on human and refugee rights. Students developed solidarity with the refugee population with which they worked. Students achieved varying degrees of conscientization as a result of their course readings, classroom discussions, and service experiences with refugees. And students critically examined their own beliefs and values in light of course materials, discussions, and service experiences.

Nevertheless, based on my review of the students' reflections, those cited and those not cited, I cannot truthfully say that students were "radicalized" as a result of the course. Three troubling themes emerged as I reread and reflected on their essays.

First, although confronted with overwhelming evidence of U.S. abuses of human rights and inadequate refugee policies, many of the students maintained a naïve optimism relative to future changes in U.S. policies. For example, in her final exam response to the essay question about the negative impact of the "war on terror" on human rights protections, following a masterful summary of the evidence in support of that premise, Karen concluded by stating:

Even though it was easier to find support for Hicks' claims, I cannot help but be optimistic towards the possibility of policy changes that will result in the promotion of human rights today. What these authors fail to recognize is the fact the exposure of these policies to the American public have led and will continue to lead to putting the spot light on the government and to force it to improve its policies concerning national and international respect of human rights. These are evident in cases brought against those individuals and their superiors that are suspected of violating human rights in the many parts of the world. These include officers from Abu Ghraib prison. Supreme Court decisions denouncing the detention of individuals without charges is also worth mentioning. Although I do not deny the damage that was done, there is still room for improvement and America is still in a position, as the leading power of the world, to right the wrongs that were carried out and to make sure that they do not happen again.

A second theme that emerged was an unquestioning belief in liberal democracy as the type of government bestsuited for the protection of human rights. This belief is implicit in the conclusion of Karen's exam essay. Laura also notes the superiority of liberal democratic forms of government, even with respect to ensuring and protecting social, cultural, and economic rights, noting, "As a democratic liberal country I think that standards of economic, cultural and social rights are what the government should strive to meet. A government that respects the economic, social and cultural rights can actively assist those rights that people are unable to enjoy." Although part of the course was devoted to a comparative analysis of national and regional human rights approaches, students clearly believed that U.S.-style liberal democracy was superior to those alternatives, even in light of evidence to the contrary.

The third theme that emerged was the students' commitment to belief in the power of individuals to make a difference. This belief was not only applied to themselves in their belief in their power to make a difference in the 
lives of the refugees with whom they worked, but in the individual power of the refugees to make a difference in their own lives. For example, referring to the benefits she received from her interactions with the refugees, Laura wrote:

I feel so great when I can offer my assistance to these refugees. I have received such happiness that has resonated throughout my life. I know that this is the beginning of an enriching experience. I can take my increasing knowledge on refugees and apply that to my want to help others. By interacting with some members from Burma I have realized how they enjoy being accepted. I can share my experiences with my friends and family as a way to spread conversation and action on human rights.

In applying Nussbaum's capabilities approach to his reflection on his work with the refugees, Frank observed, "It is important, regarding the capabilities approach to help the refugees understand their potential and capabilities [as individuals] before we or the government can help transition them to be able to attain these." I do not dispute the students' conclusions about the roles and responsibilities of individuals in promoting and supporting refugees. What troubles me in my review of their reflections is their seeming inability to recognize and reflect on the larger structural and cultural factors that also come into play.

What these themes indicate to me is that I did not sufficiently challenge my students to identify and question their fundamental beliefs in the "rightness" of U.S.-style liberal democracy and its concomitant focus on the power of individuals and self-reliance and self-sufficiency. Even among the students that I identified as politically liberal, these beliefs were firmly entrenched. This conclusion therefore leads me to question my "stealth radicalism" approach. Should I be satisfied with the results that I did achieve, or should I take a more direct approach to challenging students' unquestioning confidence in the ultimate goodness of the United States and the superiority of individualism over collectivism? How will I overcome the resistance that I expect will result from direct challenges to those beliefs? Perhaps I tried to accomplish too much in this course and should have focused exclusively either on refugee rights or the effects of the war on terror on international human rights. Would a more focused emphasis in the content have made a difference? These are questions with which I still struggle.

One aspect of the course that I would not change, however, is the service-learning component. I do believe that the impact of the course would have been minimized had it not been for the students' direct contact with refugees and our partner organization. Before this course, students did not know that their home city had a significant refugee population. Nor would they have known that refugees had legal residential status in the United States. Nor would they have known that many refugees spend years in "temporary" camps waiting for placement in a permanent host country. They would not have known how difficult and challenging the transition is from living in a refugee camp to living in the United States. Most importantly, they would not have had a personal point of reference from which to critique U.S. human rights and refugee policies 


\section{Notes}

1. The sources referred to are Nussbaum, 2006; Galtung \& Wirak, 1977; Forsythe, 2006; and Claude, 2006.

2. For a full description of the service-learning project, see Appendix 2.

3. See also Himley, 2004; Mitchell, 2008; Purpel, 1999; Saminathan, 2007; Westheimer and Kahne, (Eds.), 2007 ; and Varlotta, 1997.

4. The Convention and Protocol Relating to the Status of Refugees can be found at http://www.unhcr.org/3b66c2aa10.html .

\section{References}

Butin, D.W. (2006). The limits of service-learning in higher education. The Review of Higher Education, 29(4), 473-498.

Claude, R.P. (2006). What do human rights NGOs do? In R.P Claude and B.H. Weston (Eds.), Human rights in the world community: Issues and action ( $3^{\text {rd }}$ ed.) (432-434). Philadelphia: University of Pennsylvania Press.

Claude, R. P. \& Weston, B.H. (Ed.). (2006). Human rights in the world community: Issues and action (3 ${ }^{\text {rd }}$ ed.). Philadelphia: University of Pennsylvania Press.

Dewey, J. (1910). How we think. Lexington, MA: D.C. Heath.

Falk, R. (2005). Human rights: A descending spiral. In R.A. Wilson (Ed.), Human rights in the 'war on terror' (225-243). Cambridge, UK: Cambridge University Press.

Forsythe, D.P. (2006). Human rights in international relations (2d ed.). Cambridge, U.K.: University of Cambridge Press.

Freeman, M. (2005). Order, rights and threats: Terrorism and global justice. In R.A. Wilson (Ed.), Human rights and the 'war on terror' (3756). Cambridge, UK: Cambridge University Press.

Freire, P. (1998). Cultural action and conscientization. Harvard Education Review, 68(4), 499-521.

Galtung, J. and Wirak. A.H. (1977). Human needs and human rights: A theoretical approach. Security Dialog, 8(3), 251-258.

Goldstone, R. (2005). The tension between combating terrorism and protecting civil liberties. In R.A. Wilson (Ed.), Human rights in the 'war on terror' (157-168). Cambridge, UK: Cambridge University Press.

Hicks, N. (2005). The impact of counter terror on the promotion and protection of human rights: A global perspective. In R.A. Wilson (Ed.) Human rights in the 'war on terror' (209-224). Cambridge, UK: Cambridge University Press.

Himley, M. (2004). Facing (up to) 'the stranger' in community service-learning. College Composition and Communication, 55(3), 416-438.

Koh, H.K. (2006). How is international human rights law enforced? In R.P. Claude \& B.H. Weston (Eds.), Human rights in the world community: Issues and action ( $3^{\text {rd }}$. ed.) (305-313). Philadelphia: University of Pennsylvania Press.

Mitchell, T.D. (2008). Traditional vs. critical service-learning: Engaging the literature to differentiate two models. Michigan Journal of Community Service-Learning, Spring, 50-65.

Morton, K. (1985). The irony of service: Charity, project, and social change. Michigan Journal of Community Service-Learning, 2(1), 19-32.

Nussbaum, M.C. (2006). Capabilities, human rights, and the Universal Declaration. In R.P. Claude \& B.H. Weston (Eds.), Human rights in the world community: Issues and action ( $3^{\text {rd }}$ ed.) (27-36). Philadelphia: University of Pennsylvania Press.

Purpel, D.E. (1999). Service-learning: A critique and affirmation. Counterpoints, 102, 99-108.

Rose, D. (2004). Guantánamo: The war on human rights. New York: The New Press.

Swaminathan, R. (2007). Educating for the "real world": The hidden curriculum of community service-learning. Equity \& Excellence in Education, 40(2), 134-143.

Varlotta, L.E. (1997). A critique of service-learning definitions, continuums, and paradigms: A move towards a discourse-praxis community. Educational Foundations, 11(3), 53-85.

Westheimer, J. \& Kahne, J. (Eds.) (2007). Equity \& Excellence in Education, 40(2), 97-183. Special issue on service-learning and social justice education.

Wilson, R.A. (Ed.). (2005). Human rights in the 'war on terror.' Cambridge, UK: Cambridge University Press.

RADICAL TEACHER
No. 104 (Winter 2016)

DOI $10.5195 /$ rt.2016.258 


\section{Appendix 1}

Syllabus

Course: POLS Y380, Section 400, Special Topics in Democratic Government: Human Rights

Required Texts: Human Rights in the World Community, Eds. Prichard Pierre Claude and Burns H. Weston (hereafter Claude and Weston); Human Rights in International Relations, $2^{\text {nd }}$ Edition, by David P. Forsythe (hereafter Forsythe); Human Rights in the "War on Terror". Ed. Richard Ashby Wilson (hereafter Wilson); and supplemental readings as assigned. Supplemental readings will be available through the Oncourse site under the Tools tab.

Description: The study of human rights is by nature interdisciplinary, bringing together elements of philosophy, history, political science, anthropology, and international law. Although our focus will be seen through the political science lens, these other disciplines will appear in our readings, particularly international law. The course is structured around three themes. The first theme has to do with the evolution of human rights' definitions and practices since the end of World War II. The post-World War II era of human rights significantly expanded the definitions of human rights from an emphasis on political and civil rights, to the articulation of economic and social rights, and more recently to so-called "third generation" rights, which emphasize a variety of collective rights. As definitions of human rights expanded, so too did the laws and institutions designed to protect those rights. During the first half of the course we will focus on that evolution.

The second theme has to do with the impact of the "war on terror" on both the definition and protection of human rights. This issue raises important philosophical and practical matters dealing with state sovereignty, the role of armed, nonstate actors, and the degree to which national and international laws and institutions are equipped to support both a nation's right to self-defense and the protection of universal human rights. The issue forces us to ask such questions as

--Do "terrorists" have human rights?

--If so, what human rights' laws and institutions apply to them?

--Do human rights laws apply only to nation-states, or do they apply to individuals?

--Is there a way to balance the state's right to defend itself from internal and external terror and the state's obligations under international human rights laws?

--Should nation-states approach terror from a "law enforcement" approach or from a "war" approach? What's the difference between those approaches and what impact does that distinction have on human rights protections?

The third theme has to do with the real-world protection of human rights. One component of the laws and institutions designed to protect human rights deals with refugees. Refugees are individuals who enjoy a particular type of legal status due to severe threats to their lives because of civil war or other types of political and civil violence ongoing in their home countries. Under international law, other nation states have legal obligations to provide refugees with safe harbor. We will examine the role of international, national, and non-governmental organizations in protecting refugees through readings, discussions, and service learning. Service learning is a learning activity in which students engage course material through focused community service. For this course, you will provide community service to $x x x x x$, a non-profit organization that helps with the resettlement process of refugees who have been relocated to xxxxx by the U.S. State Department.

\section{Learning Objectives}

As a result of this course you will be able to

--Define human rights from a variety of philosophical and legal perspectives;

--Describe the key elements of $1^{\text {st }}, 2^{\text {nd }}$, and $3^{\text {rd }}$ generation human rights;

--Identify the international treaties and institutions designed to protect those rights;

--Describe the interaction of international organizations, national governments, and non-governmental organizations in protecting human rights;

--Explain the political, historical, and social circumstances that contributed to the evolution of human rights;

--Define "refugee" from a human rights perspective;

--Describe the processes by which individuals receive refugee status;

--Describe the role of international governmental organizations (IGOs), national governments, and non-governmental organizations (NGOs) in assisting refugees;

--Evaluate the work of IGOs, national governments, and NGOs in assisting refugees;

--Explain why refugee assistance is or is not a key element of international human rights protection; 
--Explain the impact of the war on terror on contemporary definitions of and protections for international human rights;

--Evaluate the U.S. response to the September 11, 2001 terrorist attacks from the perspective of international human rights law.

Assignments and Course Grades

Service Learning Project: Service-learning is a teaching technique in which course material is explored through individual or group service to a community organization. Each member of the class will provide no less than fifteen hours of service to Genesis, Inc. Service opportunities with Genesis are described on their webpage, which can be accessed in the Resources section of our Oncourse site.

To connect this project to course material, we will be reading and discussing documents from the United Nations and the U.S. State Department related to refugees and refugee programs. Through our discussions and your written reflections, you will also connect your work with refugees to broader human rights concerns. Your grade for this component of the course will be determined by your participation in the project and by the quality of your reflective essays, guidelines for which are available in the Resources section of the Oncourse site. Your participation and journal grades will be worth up to 300 points.

\section{Appendix 2}

POLS 380 Human Rights

\section{Service-learning project with Genesis}

What: Provide a minimum of fifteen service hours to Genesis. Genesis provides a variety of programs in furtherance of its mission to "support the victims of persecution, injustice, and war, as they rebuild their lives and regain basic human rights and needs." (Italics added)

\section{Why should I provide fifteen hours of service and what does this have to do with this course?}

Service learning is a widely recognized teaching strategy that integrates academic study with organized student service. Classroom study on its own helps students gain some understanding of academic content, but frequently that content remains in the realm of the abstract. Your service learning experience with Genesis will make real many of the abstract concepts we will study in this course. For example, it will allow you to become part of what political scientists refer to as an international regime by participating in an international human rights network-in this case, a network that assists with the relocation and resettlement of families and individuals who face grave physical danger in their own countries and, frequently, from their own governments. It will also allow you to see firsthand the important role that non-governmental organizations (NGOs) play in implementing national and international policies with respect to nation states' human rights obligations. Without having this service learning experience, these highlighted terms would simply be concepts to be studied through lecture and reading, but they would probably not have much personal or emotional significance. For most, if not all of you, your experience with Genesis will provide "real" meaning to the words you read and hear as part of the course.

\section{Appendix 3}

\section{POLS 380: GUIDELINES FOR THE ANALYTICAL SUMMARY OF}

\section{SERVICE-LEARNING EXPERIENCE}

Your analytical summary (5-7 typewritten pages) should be in three sections and should address the following questions.

I. Description

- Describe your service-learning activities. What did you do, how often, in what settings?

- What challenges/problems did you encounter in fulfilling the service-learning requirement?

- What did you do to resolve those problems?

II. Integration

-Review the following report to find out about the U.S. State Department's plans for refugee resettlement for 2008: 
The report is easier to read if you click on the link to the PDF version. This report is also available under the Tools tab. Pay particular attention to the section dealing with Priority Admissions. After you have reviewed the content of the report, answer the following questions:

Based on the information in the report, have your perceptions of whether the U.S. does enough to support refugees changed? Why or why not? What specific information or experience(s) changed/confirmed your perceptions?

Do the countries of origin prioritized by the U.S. for refugee resettlement reflect the areas of greatest humanitarian crisis and need? On what information do you base your conclusion?

Based on your experiences working with Genesis, what do you consider to be the strengths and weaknesses of the State Department's refugee resettlement goals?

How does "the war on terror" impact U.S. refugee policy?

\section{Evaluation}

- What did you learn about Genesis and its role in working with refugees?

- How are its programs contributing to the integration of refugees into local and national life?

- What did you learn about yourself, about your own strengths and limitations?

- How would you change the service-learning experience to make it a more valuable learning experience? In what ways could I as an instructor have been more effective in facilitating your learning from this experience?

- Has your experience made your classwork and reading more meaningful/relevant? Why or why not? Please refer to specific concepts and authors in your response. 